可視化情報 Vol.13 Suppl. No.1（1993年7月）

\title{
43 マイクロカプセル化された感温液晶䊒子の光学的特生
}

\author{
東大生研都德熙、小林敏雄、佐賀徹雄、瀬川茂樹
}

Optical characteristics of micro-capsulized cholesteric liquid crystal

Deoghee DOH*, Toshio KOBAYASHI*, Tetsuo SAGA*, Sigeki SEgAWA*

Generaliy, the temperature change of the cholesteric liquid crystals causes a shift in molecular structure and, thus a different color at a constant observation angle. On top of it, when the microencapsulation process for stabilizing the cholesteric liquid crystal and converting it into an easily manipulable form is fulfilled, the micro-capsuilzed cholestric liquid crystals act as a three-dimensional diffraction grating for light of visible wavelengths and show similar behavior to the Bragg scattering effects observed in crystalline solids. Since this Bragg-type scattering gives rise to the characteristic iridescent colors around the micro-capsulized cholesteric liquid crystal, their spatial. spectral color distribution around it needs to be known for applying it to the temperature measurements. This study focuses on the above optical characteristics of the micro-capsulized cholesteric liquid crystals.

1 .

はじめに

温度の变化によって色が変わる特徽を持っている感温液晶を利用し、熱伝達や熱対流現 象を研究する武みがなされているいいる感温液晶は低分子コレステリック液晶で、化学 的に安定な物質でないため、直径が数十 $+\mathrm{m}$ から数十 $\mathrm{m} \mathrm{m} の$ 球形のマイクロカプセルに封 入して化学的污染及び物理的損傷加ら保護される。このようなマイクロカプセル化された 感温波晶粒子を用いて温度を計剆する場合には、温度に対する色の变化の特性を調へる必 要がある。さらに、カプセル化された感温波晶粒子への入射光上撮影角度に対方る光学的 な特性もあらかじめ調べる必要がある。本研究では、マイクロかプセル化さ扎た感蕰液晶 精子の入射光と撮影角度との成す相対角度を変化させ、その光学的な特性を調へたので報 告する。

2、マイクロカプセル化された感温液晶の光学的特性 $2-1$ 光学 的特性

コレステリク液晶の光学的な特㟨として、光学的活性、 複屈折、丹偏光 2 色性、温度依存性等があげられる。コレ ステリック被晶をマイクロカプセル化した場合にはブラッ グスキ+ッタリング(3)現象が起き、图1のように入射光に 対する色の空間分在驾形成される。このた、入射光に対 して視線角度を变えると異なる波長の色が観察される。

$$
2-2 \text { 実疆と考察 }
$$

図2 は感温液晶粒子( AR 1 5 C 2 5 R、 $d=500 \mu \mathrm{m}$ 、此重 1.02 ) への入射光（泠光線、八ロゲンランプ、1 150 w) とカメ ラ（ 3 板式CCD、力ラ一、S S n y D XC-3000A) 吕成す相対角度 $\theta$ による液晶粒子の色相の変化を较正する実験である。較 正実験は液晶粒子温度を一定に保古、相対角度 $\theta$ を変化さ

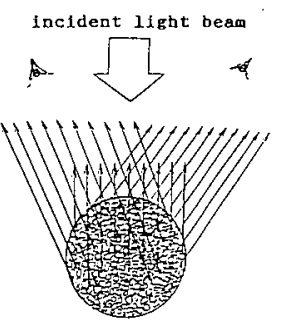

Fig.1 Bragg scattering

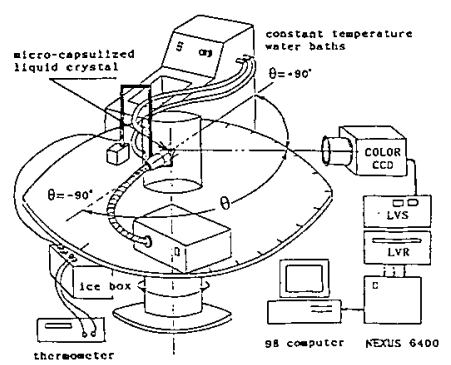

Fig. 2 Experimental apparatus

Institute of Industrial Science, Univ. of Tokyo 7-22-1 Roppongi, Minatoku,Tokyo 
せて行った。また、液晶粒子の温度を変化させた場合の $\theta$ と色变

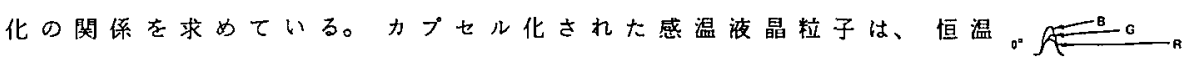
水槽内下、直径 $2.5 m \pi$ 厚さ0.5 mmの細い球形ガラス管の中で固 定されている。液晶粒子温度は、波晶粒子に近接して設置された 熱電対で計即した值を勘準とした。液鮊粒子、光䃇、及びカメう を同一平面内に設置し、これらが成す角度 $\theta$ を 90 度の間で 5 度間隔で变化させカラーデータを採取した。カメラからのRGB アナログ信号の記録には、レーザビデオレコーダ（Sony LVR,LVS 5000 )を、また画像の解析にはイメージプロセッサ(Nexus 6400 〉を用いた。図 3 に液晶の温度が $20{ }^{\circ} \mathrm{C} の$ 場合の液晶粒子のR G Fi.g. 3 RGB Histogram on the $B \equiv$ 成分の頻度分布を示す。 $\mathrm{R} G \mathrm{~B}$ の值は液晶粒子の中心線上の 濃度值を意味する。相対角度 $\theta$ により色相が変化する事、また 相対角度の正負の角度が等しい場合には、類似の色分布を持つ事 が分かる。これは、光源とカメラの相対角度が一定ならば、類似 の波長の光が観察される事意味する。図4 に相対角度を0度か ら45度まで 1 度間隔で变えた場合の、感温液昆粒子の色相值( H）の变化を示す。感温液晶粒子の温度を一定にして角度を变え た場合、 $\mathrm{H}$ 值が角度により变化している事が分加る。また、 $\mathrm{H}$ 值 と $\theta$ の関係が温度により翼なる特性を持つ事む分加る。图中、あ る角度鞍囲で $\mathrm{H}$ がステップ的な变化をしているのはカメラを含む 画像処理システム系の分解能不足のためであると推定される。 3. まとめ

マイクロカプセル化された感温被晶粒子の光学的特性を調へた 結果以下の上うな結論を得た。

(1)マイクロカブセル化された感温液晶粒子にはのブラッグス キャッタリング現象がある事を定量的に示した。

（2）また、その感温液晶粒子の光学特性は温度ことに異なる事 を示した。

（3）光源とカメラの相対角度が大きくなるような計湖では、あ らかし旅晶粒子の光学特性を較正する必要がある事を示 した。

現在、画像入力器機の特性および液晶粒子の温度に対する時間纫 答性などについて研究を進めている。

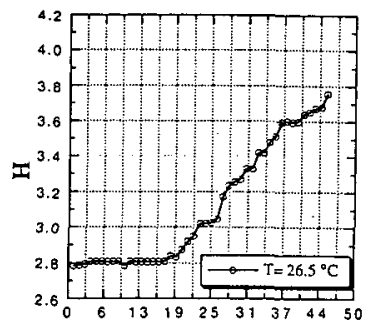
Angle
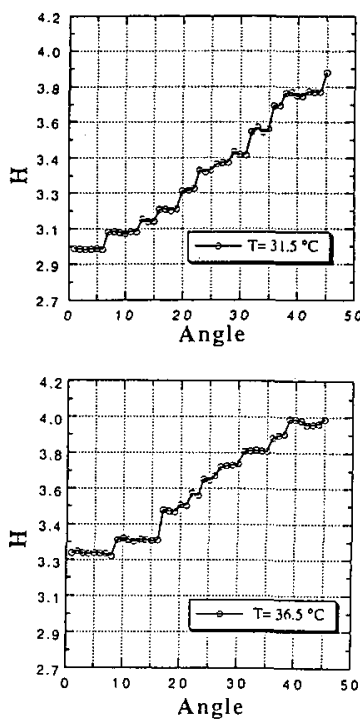

Fig. 4 Hue versus angle

4. 参考文献

（1）小林敏雄、佐賀徽雄、瀨川茂樹、可視化情報、Vol.12.Suppl.No.1(1992).pp71

(2) Philomena G. Grodzka, Letters in Heat and Mass Transfer Vol.2(1975).pp169

(3) P. Carroll, Cholesteric Liquid Crystals, ovum Ltd. (1973). 